\title{
Produksi Kedelai (Glycine max (L.) Merrill) Organik dengan Berbagai Dosis dan Cara Aplikasi Pupuk Kandang Kambing
}

\section{The Production of Organic Soybean (Glycine $\max (L) M e r r i l l$.$) with Various Rates and$ Application Methods of Goat Manure}

\author{
Fitri Galih Kurnia dan Maya Melati*
}

Departemen Agronomi dan Hortikultura, Fakultas Pertanian, Institut Pertanian Bogor (Bogor Agricultural University), J1. Meranti, Kampus IPB Darmaga, Bogor 16680, Indonesia

Telp.\&Faks.62-251-8629353 e-mail agronipb@indo.net.id

*Penulis untuk korespondensi: mayamelati14@gmail.com

Disetujui 14 Mei 2018 / Published online 21 Mei 2018

\begin{abstract}
Soybean is one of the food crops as source of vegetable protein that can be cultivated with organic farming system. The objective of this study was to get optimal rate of goat manure and proper manure application to increase production of organic soybean. The experiment was conducted at Cikarawang, Bogor from April until August 2014. The experiment used randomized complete block design with two factors and three replications. The rates of goat manure were $0,6,12,18$ ton/ha while the application methods of goat manure were put in planting row and spread over the soil surface. The interaction effect between rate of goat manure and application method was significant on dry weight of 100 seeds, but it was not significant on the yields. The highest number of pods/plant (40,6 pods) was obtained from 18 ton goat manure/ha with the potential yield of 2,2 ton/ha. The highest number of pods/plant(27 pods) was reached with application of manure in planting row. Refering to results, it can recommended that goat goat manure can be applied in row or spread over the soil surface with 18 ton goat manure/ha to increase the production of organic soybean.
\end{abstract}

Keywords: arbuscular mycorrhizal fungi, double row spacing, organic farming.

\begin{abstract}
ABSTRAK
Kedelai merupakan salah satu komoditas pangan sumber protein nabati yang memiliki potensi diproduksi dengan sistem pertanian organik. Tujuan percobaan ini untuk mendapatkan dosis pupuk kandang kambing optimal dan cara aplikasi pupuk yang tepat untuk meningkatkan produksi kedelai organik. Percobaan dilaksanakan di Kebun Cikarawang, Bogor pada bulan April sampai Agustus 2014. Percobaan ini menggunakan rancangan kelompok lengkap teracak dengan dua faktor perlakuan terdiri atas dosis pupuk kandang kambing $(0,6,12$, dan 18 ton/ha) dan cara aplikasi pupuk (alur dan sebar) dengan tiga ulangan. Hasil percobaan menunjukkan bahwa pengaruh interaksi dosis dan cara aplikasi pupuk sangat nyata pada bobot kering 100 butir biji namun tidak nyata pada produktivitasnya. Jumlah polong isi per tanaman tertinggi (40,6 polong) dari pemberian 18 ton pupuk kandang kambing/ha dengan produktivitas 2,2 ton/ha. Jumlah polong isi per tanaman terbanyak (27 polong) dihasilkan dari cara aplikasi pupuk dalam alur. Berdasarkan hasil tersebut, dapat disarankan cara aplikasi pupuk alur atau sebar dengan dosis rekomendasi 18 ton pupuk kandang kambing/ha dapat meningkatkan produksi kedelai organik.
\end{abstract}

Kata kunci: fungi mikoriza arbuskula, jarak tanam ganda, pertanian organik 


\section{PENDAHULUAN}

Kedelai merupakan salah satu komoditas pangan utama di Indonesia. Kebutuhan kedelai rata-rata Indonesia sekitar 2,20 juta ton/tahun. Hingga saat ini produksi kedelai dalam negeri hanya mampu mencukupi $35-40 \%$ kebutuhan nasional, sehingga kekurangannya dipenuhi dari impor (Marwoto dan Suharsono, 2008). Kedelai lebih banyak diproduksi dalam bentuk olahan dibandingkan tidak diolah, serta permintaan pasar terhadap kedelai terus meningkat setiap tahunnya. Melati dan Andriyani (2005) menyatakan bahwa jika kedelai dapat diproduksi melalui sistem pertanian organik, maka nilai ekonominya dapat meningkat seperti halnya pada produk organik lainnya. Permintaan pangan organik meningkat dengan semakin banyaknya masyarakat di dunia yang mengikuti gaya hidup sehat 'back to nature'. Konsumen menginginkan pangan yang aman, bernutrisi tinggi, dan ramah lingkungan.

Pertanian organik merupakan sistem pertanian yang memanfaatkan bahan organik dalam bentuk produk buangan tanaman ataupun ternak dengan tujuan untuk memperbaiki sifat fisik, kimia, dan biologi tanah. Tanah dan sumber air dikelola dengan baik sehingga residu kimia yang terkandung dalam produk selama budidaya dapat diminimalisasi (Simanungkalit dan Suriadikarta, 2006). Pupuk organik, kombinasi dan residunya dapat digunakan untuk memenuhi kebutuhan hara tanah untuk produksi kedelai. Abu sekam padi dapat menurunkan intensitas serangan hama, tetapi sebaiknya tidak diberikan secara tunggal melainkan dikombinasikan dengan pupuk organik yang lain (Melati et al., 2008).

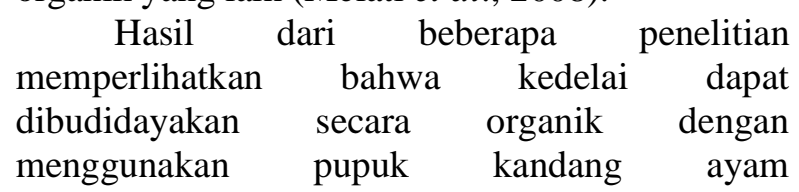
(Kurniansyah, 2010; Meliala, 2011; Handayani, 2012; Roziqin, 2014). Hartatik dan Widowati (2005) menyatakan pupuk kandang kambing mampu menyediakan unsur hara yang dapat meningkatkan pertumbuhan dan produksi tanaman. Kadar hara pupuk kandang kambing mengandung kalium yang relatif lebih tinggi dari pupuk kandang lainnya. Oleh karena itu perlu diuji penggunaan pupuk kandang kambing untuk produksi kedelai secara organik.

Hartatik dan Widowati (2005); Jumini et al. (2011) menyatakan bahwa pupuk kandang dapat diaplikasikan dengan berbagai cara di lahan kering yaitu disebar di permukaan tanah kemudian dicampur pada saat pengolahan tanah, dalam larikan, dalam lubang-lubang tanam, dan disemprotkan melalui daun. Hasil penelitian
Jumini et al. (2011) menunjukkan bahwa cara pemupukan terbaik bagi tanaman jagung manis adalah dengan cara ditempatkan dalam larikan di antara barisan tanaman karena unsur hara yang diserap tanaman lebih banyak sehingga produksi lebih tinggi.

Tujuan penelitian adalah untuk mempelajari pengaruh berbagai dosis dan cara aplikasi pupuk kandang kambing, serta mempelajari pengaruh kombinasi antara perlakuan tersebut terhadap produksi kedelai yang dibudidayakan secara organik.

\section{BAHAN DAN METODE}

Percobaan dilaksanakan di Kebun Cikarawang, Dramaga, Bogor pada bulan April sampai Agustus 2014. Bahan tanam yang digunakan dalam percobaan adalah benih kedelai varietas Anjasmoro yang tidak diberi seed treatment berupa rhizobium. Pupuk organik yang digunakan adalah pupuk kandang kambing dengan dosis sesuai perlakuan ditambah 2 ton Tithonia diversifolia/ha, 1 ton abu sekam/ha. Peningkatan $\mathrm{pH}$ tanah dilakukan dengan menggunakan kapur pertanian dengan dosis 2 ton/ha. Pengendalian yang dilakukan agar mengurangi terjadinya serangan hama dan penyakit adalah penggunaan pestisida alami berupa larutan kulit jengkol dengan volume semprot $400 \mathrm{~L} / \mathrm{ha}$. Tanaman penghambat Organisme Pengganggu Tanaman (OPT) yang digunakan adalah tanaman serai wangi (Cymbopogon nardus) berasal dari percobaan sebelumnya yang berada dipinggir blok percobaan. Inokulum Fungi mikoriza arbuskula (FMA) dari Laboratorium Pusat Penelitian Sumberdaya Hayati dan Bioteknologi IPB dengan dosis $1 \mathrm{~g}$ per lubang tanam. Alat yang digunakan adalah alat budidaya pertanian dan alat-alat untuk pengamatan.

Rancangan percobaan yang digunakan adalah Rancangan Kelompok Lengkap Teracak (RKLT) dengan dua faktor yang disusun secara faktorial. Faktor pertama adalah dosis pupuk kandang kambing dengan 4 taraf yaitu $0,6,12$, dan 18 ton ha ${ }^{-1}$. Faktor kedua adalah cara aplikasi pupuk kandang kambing dengan 2 taraf yaitu dalam alur dan secara sebar pada petakan. Kedua faktor tersebut disusun menjadi 8 perlakuan yang masing-masing diulang sebanyak 3 kali sehingga diperoleh 24 satuan percobaan. Data dianalisis dengan sidik ragam dan apabila hasilnya menunjukan pengaruh yang nyata, maka dilakukan uji lanjut dengan Duncan Multiple Range Test dengan taraf kesalahan 5\%. 
Lahan percobaan dikelompokkan menjadi tiga ulangan. Masing-masing ulangan menjadi sampel untuk dianalisis hara tanah di Laboratorium Analisis Tanah, Departemen Manajemen Sumberdaya Lahan, Fakultas Pertanian, Institut Pertanian Bogor. Tanah diolah, digemburkan dan ditambahkan abu sekam kemudian dibuat petakan dengan ukuran petak 3 $\mathrm{m} \times 2,4 \mathrm{~m}$ pada 4 minggu sebelum tanam. Pupuk kandang kambing, Tithonia diversifolia, dan kapur pertanian diaplikasikan pada 3 minggu sebelum tanam kedelai.Jarak tanam yang digunakan adalah jarak tanam ganda (double row) $20 \mathrm{~cm}$ x $20 \mathrm{~cm} \times$ $40 \mathrm{~cm}, 2$ benih per lubang taman, sehingga populasi tanaman kedelai 333.333 tanaman/ha. Aplikasi Fungi mikoriza arbuskula (FMA) dengan dosis $1 \mathrm{~g}$ per lubang tanam bersamaan dengan penanaman benih kedelai tanam. Penyulaman tanaman kedelai dilakukan satu minggu setelah tanam. Pengendalian hama dan penyakit tanaman dengan cara menyemprotkan pestisida alami berupa larutan kulit jengkol pada 7 dan 8 MST, pembersihan gulma, dan pembumbunan.

Panen biji kering kedelai dilakukan saat masuk masak panen. Kedelai siap panen jika 70\% daun telah menguning, kering, dan polong menjadi keras serta warna kulit polong menjadi kecoklatan (Purwono dan Purnamawati, 2007). Pemanenan dilakukan dengan mencabut tanaman secara utuh. Pengamatan dilakukan pada komponen pertumbuhan dan produksi yaitu tinggi tanaman, jumlah daun trifoliet, intensitas serangan hama dan penyakit, umur berbunga, bobot basah dan kering (daun, tajuk, akar, dan bintil akar), analisis hara daun, jumlah tanaman panen/petak, jumlah buku produktif, jumlah polong per tanaman, jumlah polong isi per tanaman, jumlah polong hampa per tanaman, bobot kering 100 butir biji, bobot kering biji petak bersih, dan produktivitas.

\section{HASIL DAN PEMBAHASAN}

\section{Kondisi Umum}

Berdasarkan kriteria penilaian sifat-sifat kimia tanah menurut Pusat Penelitian Tanah (1983), hasil analisis tanah menunjukkan reaksi tanah agak masam pada ketiga blok tanah. Kadar C-organik pada ketiga blok tanah berada pada kategori rendah dengan nilai rata-rata $1,59 \%$. Sifat tanah $\mathrm{P}$ total berada dalam golongan tinggi, namun kadar $\mathrm{N}, \mathrm{P}$ tersedia, dan $\mathrm{K}$ tergolong rendah. Rendahnya ketersediaan hara merupakan indikasi adanya pengaruh kemasaman tanah. Hardjowigeno (2007) menyatakan bahwa P berperan dalam pembentukan bunga, buah, dan biji. Fosfor yang rendah dan reaksi tanah yang agak masam menjadi salah satu faktor pembatas di lahan pertanaman kedelai.

C-organik pada ketiga blok percobaan berada pada kategori rendah, hal ini disebabkan oleh kurangnya residu pupuk yang terdapat pada tanah dari musim tanam sebelumnya. Upaya untuk meningkatkan $\mathrm{C}$-organik adalah dengan penggunaan pupuk organik seperti pupuk kandang dan pupuk hijau. Lestari (2011) menyatakan bahwa Tithonia diversifolia mengandung Corganik sebesar $54,90 \%, 3,06 \% \mathrm{~N}, 0,25 \% \mathrm{P}$, dan $5,75 \% \quad \mathrm{~K}$ sehingga dapat meningkatkan kandungan bahan organik tanah.

Hasil analisis KTK tanah pada ketiga blok masih tergolong rendah. Hardjowigeno (2007) menyatakan bahwa tanah dengan KTK tinggi mampu menyerap dan menyediakan unsur hara sehingga akan meningkatkan kesuburan tanah. Kasnoet al. (2009) menjelaskan bahwa pemberian pupuk organik dapat meningkatkan nilai KTK tanah, $\mathrm{pH}$ tanah, dan unsur $\mathrm{P}$. Winarni et al. (2013) menyatakan bahwa salah satu pupuk organik yang digunakan pada percobaan adalah pupuk kandang kambing yang memiliki C-organik $26,30 \%, \mathrm{~N}$ total $1,56 \%$, dan $\mathrm{C} / \mathrm{N}$ rasio 16,86 .

Berdasarkan data cuaca dari BMKG Dramaga (2014), selama penelitian rata-rata curah hujan kurang dari $150 \mathrm{~mm}$, kelembaban udara $83,8 \%$, dan suhu lingkungan selama percobaan yaitu $25,7-26,9{ }^{\circ} \mathrm{C}$, angka tersebut menunjukkan bahwa suhu lingkungan pada kondisi yang sesuai untuk pertumbuhan maksimal kedelai. Data curah hujan menunjukkan kondisi yang fluktuatif, selama percobaan curah hujan di bawah $150 \mathrm{~mm}$. Pertumbuhan benih pada 1 MST hanya berkisar $36,8-47,8 \%$ sehingga dilakukan penyulaman. Curah hujan yang rendah pada fase vegetatif yaitu $12,2 \mathrm{~mm} /$ bulan juga menyebabkan benih kekurangan asupan air. Kondisi kekeringan menjadi sangat kritis saat tanaman kedelai berada pada fase pengisian polong (6-11 MST) dengan curah hujan mencapai titik terendah yaitu 6,7 $\mathrm{mm}$. Sumarno dan Mashuri (2007) menyatakan bahwa kebutuhan curah hujan yang merata 100$450 \mathrm{~mm} / \mathrm{bulan}$ pada dua bulan sejak tanam merupakan kondisi yang cukup baik bagi pertumbuhan kedelai.

Pertanaman kedelai secara umum menunjukkan kondisi yang baik. Intensitas serangan hama dan penyakit tanaman rendah. Hama dan penyakit yang menyerang tanaman kedelai pada fase vegetatif adalah belalang (Valanga sp.) dan penyakit bercak daun. Hama dan penyakit lain yang menyerang tanaman kedelai adalah ulat polong (Etiela zinchenella), kepik polong (Riptortus linearis), dan penyakit anthraknosa (cendawan Colletotrichum glucine 
Mori). Kondisi cuaca relatif tidak stabil saat fase pembentukan dan pengisian polong, dimana sering turun hujan gerimis merupakan faktor pemicu munculnya hama dan penyakit pada tanaman kedelai pada fase generatif. Pengendalian hama dan penyakit pada 7 MST dengan pestisida alami berbahan utama kulit jengkol (Pithecellobium jiringa). Rozaq dan Sofriani (2009) menyatakan bahwa Jengkol mengandung asam amino dan sulfur yang dapat membunuh dan menghambat pertumbuhan hama.

\section{Komponen Pertumbuhan Tanaman}

Komponen Pertumbuhan Kedelai dengan Perlakuan Dosis Pupuk Kandang Kambing. Hasil analisis ragam (Tabel 1) menunjukkan bahwa secara umum penambahan 18 ton pupuk kandang kambing/ha menghasilkan komponen pertumbuhan dan produksi kedelai lebih baik daripada perlakuan lainnya, meskipun tidak semuanya nyata secara statistik. Penambahan 18 ton pupuk kandang kambing/ha meningkatkan tinggi tanaman sebesar $12,62 \%$ lebih baik dibandingkan tanpa pemberian pupuk kandang kambing (0 ton/ha). Hal tersebut sesuai dengan hasil penelitian Dinariani et al. (2014) yang menunjukkan bahwa semakin bertambah dosis pupuk kandang kambing yang diberikan, semakin tinggi pula tanaman jagung manis. Asiah (2005) menyatakan bahwa perlakuan pupuk kandang mampu meningkatkan tinggi tanaman dan jumlah daun kedelai lebih tinggi karena lebih cepat terdekomposisi dibandingkan pupuk hijau atau kombinasinya.
Aplikasi pupuk kandang kambing tidak nyata meningkatkan kadar hara $\mathrm{N}, \mathrm{P}$, dan $\mathrm{K}$ daun. Nilai kecukupan kadar hara $\mathrm{N}, \mathrm{P}$, dan $\mathrm{K}$ berdasarkan Vitosh et al. (1995) yaitu N (4,25$5,50 \%)$, P (0,30-0,50\%), dan K (2,01-2,50\%). Berdasarkan kriteria tersebut tanaman kedelai organik percobaan mengalami defisiensi kadar $\mathrm{N}$, $\mathrm{P}$, dan $\mathrm{K}$ daun. Hal ini diduga akibat kondisi lingkungan selama pertanaman seperti curah hujan yang rendah berada pada kondisi yang kurang mendukung untuk menyerap unsur hara dalam tanah. Berdasarkan Roziqin (2014) kondisi lingkungan yang optimal dan peningkatan dosis FMA dapat berperan meningkatkan kepadatan spora sesudah tanam dan infeksi akar kedelai sehingga kadar hara $\mathrm{P}$ daun optimum untuk pertumbuhan kedelai. Selain hal tersebut, rendahnya kadar hara juga dapat disebabkan tidak ada Rhizobium, dan kadar hara pupuk kandang kambing lebih rendah dari pupuk kandang ayam. Hasil penelitian Santoso et al. (2004), pupuk kandang ayam memiliki kadar hara $\mathrm{N}, \mathrm{P}$, dan $\mathrm{K}$ tinggi yaitu sehingga mampu meningkatkan ketersedian hara untuk diserap oleh tanaman. Lingga (1991) menyatakan bahwa kotoran ayam memiliki kandungan $\mathrm{N}(1,5 \%), \mathrm{P}_{2} \mathrm{O}_{5}(1,3 \%), \mathrm{K}_{2} \mathrm{O}$ $(0,8 \%)$, dan kadar air (57\%). Sutedjo (1994) menyatakan bahwa pupuk kandang ayam mengandung unsur $\mathrm{N}$ tiga kali lebih besar daripada pupuk kandang yang lainnya. Kadar hara pupuk kandang ayam lebih tinggi disebabkan oleh cairan (urine) bercampur dengan bagian padat.

Tabel 1. Komponen pertumbuhan kedelai dengan perlakuan dosis pupuk kandang kambing

\begin{tabular}{|c|c|c|c|c|c|c|c|c|c|c|}
\hline \multirow{2}{*}{ Peubah } & \multirow{2}{*}{$\begin{array}{c}\text { Umur } \\
\text { (MST) }\end{array}$} & \multirow{2}{*}{$\begin{array}{c}\text { Uji } \\
\mathrm{F}\end{array}$} & \multicolumn{7}{|c|}{$\begin{array}{l}\text { Dosis pupuk kandang kambing } \\
\text { (ton/ha) }\end{array}$} & \multirow{2}{*}{$\begin{array}{r}\text { Rata- } \\
\text { rata }\end{array}$} \\
\hline & & & 0 & & 6 & 12 & & 18 & & \\
\hline Tinggi tanaman $(\mathrm{cm})$ & 7 & $*$ & 33,16 & $\mathrm{~b}$ & 32,35 & b 34,36 & $a b$ & 37,49 & $\mathrm{a}$ & 34,32 \\
\hline Jumlah daun trifoliet & 7 & $*$ & 10,0 & $\mathrm{~b}$ & 10,5 & ab 11,3 & $\mathrm{a}$ & 11,2 & $\mathrm{a}$ & 10,7 \\
\hline Kadar K daun $(\%)$ & 7 & tn & 1,27 & & 1,30 & 1,23 & & 1,30 & & 1,27 \\
\hline Kadar P daun $(\%)$ & 7 & tn & 0,16 & & 0,20 & 0,17 & & 0,19 & & 0,18 \\
\hline Kadar Ndaun (\%) & 7 & tn & 2,53 & & 2,63 & 2,59 & & 2,54 & & 2,57 \\
\hline BB tajuk (g per tanaman) & 7 & tn & 39,23 & & 36,63 & 33,38 & & 44,97 & & 38,55 \\
\hline BK tajuk (g per tanaman) & 7 & tn & 19,17 & & 17,25 & 16,25 & & 21,82 & & 18,62 \\
\hline Rasio tajuk/akar & 7 & $\operatorname{tn}$ & 12,75 & & 9,72 & 8,63 & & 9,60 & & 10,18 \\
\hline BB akar (g per tanaman) & 7 & $* *$ & 3,03 & $\mathrm{~b}$ & 3,67 & b 3,72 & $\mathrm{~b}$ & 4,80 & a & 3,80 \\
\hline BK akar (g per tanaman) & 7 & $* *$ & 1,42 & $\mathrm{~b}$ & 1,70 & b 1,53 & $\mathrm{~b}$ & 2,45 & $\mathrm{a}$ & 1,78 \\
\hline BB bintil akar (g per tanaman) & 7 & $* *$ & 0,82 & $\mathrm{c}$ & 1,62 & b 2,18 & $\mathrm{a}$ & 1,95 & $\mathrm{ab}$ & 1,64 \\
\hline BK bintil akar (g per tanaman) & 7 & ** & 0,35 & $\mathrm{c}$ & 0,80 & b 1,17 & a & 0,97 & $a b$ & 0,82 \\
\hline $\mathrm{BB}$ daun (g per tanaman) & 7 & tn & 6,75 & & 7,30 & 7,08 & & 9,10 & & 7,56 \\
\hline BK daun (g per tanaman) & 7 & $*$ & 3,23 & $\mathrm{~b}$ & 3,58 & b 3,45 & $\mathrm{~b}$ & 5,13 & $\mathrm{a}$ & 3,85 \\
\hline
\end{tabular}

Keterangan: Angka yang diikuti huruf berbeda pada baris yang sama menunjukkan berbeda nyata berdasarkan hasil Duncan's multiple range test (DMRT) pada taraf $\alpha=5 \%$, tn:tidak nyata, $(*)$ berbeda nyata pada taraf $5 \%$, $(* *)$ berbeda sangat nyata pada taraf $1 \%, \mathrm{KK}$ : koefisien keragaman, BB: bobot basah, BK: bobot kering. 
Komponen Pertumbuhan Kedelai dengan

Perlakuan Cara Aplikasi Pupuk Kandang

Kambing. Hasil analisis ragam (Tabel 2) menunjukkan bahwa secara umum cara aplikasi pupuk kandang kambing berpengaruh tidak nyata terhadap beberapa komponen pertumbuhan kedelai. Cara aplikasi pupuk dialur menghasilkan nilai yang tidak lebih baik dari pada disebar. Penelitian Jumini et al. (2011) menunjukkan bahwa cara pemupukan melingkar dan larikan sama pengaruhnya terhadap semua peubah pertumbuhan dan hasil jagung manis. Hal ini diduga pupuk $\mathrm{N}$, $\mathrm{P}$, dan $\mathrm{K}$ yang diberikan dengan cara tersebut mengakibatkan unsur hara dapat kontak langsung dengan permukaan akar,sehingga dapat diserap oleh tanaman. Hal ini sejalan dengan Sarief (1986) bahwa penempatan pupuk tepat pada perakaran (dekat akar tanaman) maka pemupukan tersebut akan membantu tanaman dalam mendapatkan hara dari tanah. Beberapa dugaan yang mengakibatkan percobaan ini menghasilkan nilai BB dan BK tajuk dan daun yang lebih tinggi pada cara aplikasi sebar adalah tanaman lebih baik dalam mengambil hara yang tersebar pada petak percobaan dengan bantuan FMA yang memiliki misellium cukup panjang sehingga dapat menjangkau pupuk yang tersebar.

Tabel 2. Komponen pertumbuhan kedelai dengan perlakuan cara aplikasi pupuk kandang kambing

\begin{tabular}{|c|c|c|c|c|c|c|c|}
\hline \multirow[t]{2}{*}{ Peubah } & \multirow{2}{*}{$\begin{array}{l}\text { Umur } \\
\text { (MST) }\end{array}$} & \multirow{2}{*}{$\begin{array}{l}\text { Uji } \\
\mathrm{F}\end{array}$} & \multicolumn{4}{|c|}{$\begin{array}{c}\text { Cara Aplikasi } \\
\text { Pemupukan }\end{array}$} & \multirow[t]{2}{*}{ Rata-rata } \\
\hline & & & dialur & & Disebar & & \\
\hline Tinggi tanaman $(\mathrm{cm})$ & 7 & tn & 34,66 & & 33,97 & & 34,31 \\
\hline Jumlah daun trifoliet & 7 & tn & 10,6 & & 10,9 & & 10,7 \\
\hline Kadar K daun (\%) & 7 & $\operatorname{tn}$ & 1,22 & & 1,33 & & 1,27 \\
\hline Kadar P daun $(\%)$ & 7 & tn & 0,17 & & 0,19 & & 0,18 \\
\hline Kadar N daun (\%) & 7 & tn & 2,56 & & 2,58 & & 2,57 \\
\hline BB tajuk (g per tanaman & 7 & $*$ & 34,83 & $\mathrm{~b}$ & 42,27 & $\mathrm{a}$ & 38,55 \\
\hline BK tajuk (g per tanaman) & 7 & $*$ & 16,69 & $\mathrm{~b}$ & 20,55 & $\mathrm{a}$ & 18,62 \\
\hline Rasio tajuk/akar & 7 & tn & 9,52 & & 10,83 & & 10,18 \\
\hline BB akar (g per tanaman) & 7 & tn & 3,63 & & 3,98 & & 3,80 \\
\hline BK akar (g per tanaman) & 7 & tn & 1,76 & & 1,79 & & 1,78 \\
\hline BB bintil akar (g per tanaman) & 7 & tn & 1,62 & & 1,67 & & 1,64 \\
\hline BK bintil akar (g per tanaman) & 7 & tn & 0,78 & & 0,86 & & 0,82 \\
\hline BB daun (g per tanaman) & 7 & $*$ & 6,69 & $\mathrm{~b}$ & 8,43 & $\mathrm{a}$ & 7,56 \\
\hline BK daun (g per tanaman) & 7 & $*$ & 3,34 & $\mathrm{~b}$ & 4,36 & a & 3,85 \\
\hline
\end{tabular}

Keterangan: Angka yang diikuti huruf berbeda pada baris yang sama menunjukkan berbeda nyata, tn:tidak nyata, $(*)$ berbeda nyata pada taraf $5 \%,(* *)$ berbeda sangat nyata pada taraf $1 \%$, KK: koefisien keragaman, BB: bobot basah, BK: bobot kering.

\section{Komponen Produksi Tanaman}

Komponen Produksi Kedelai dengan Perlakuan Dosis dan Cara Aplikasi Pupuk Kandang Kambing. Pupuk kandang kambing meningkatkan jumlah tanaman panen per petak, jumlah polong per tanaman, dan jumlah polong isi per tanaman. Tabel 3 menunjukkan bahwa jumlah tanaman panen per petak tanpa pupuk kandang kambing lebih besar $21,81 \%$ dibandingkan dengan taraf lainnya, namun lebih tinggi dengan 18 ton pupuk kandang kambing/ha. Penambahan pupuk kandang kambing meningkatkan hasil kedelai hingga 22,16\% daripada tanpa pupuk kandang kambing.

Cara aplikasi pupuk kandang kambing berpengaruh tidak nyata pada semua peubah produksi kedelai (Tabel 4). Hal tersebut menunjukkan bahwa cara aplikasi pemupukan sebar dan alur memiliki pengaruh yang sama terhadap peubah produksi. Pemberian FMA memungkinkan jangkauan akar bisa lebih jauh akibat adanya miselium sehingga hara dari pupuk yang disebar dapat diserap oleh akar tanaman. Lakitan (1995) menunjukan bahwa unsur hara dapat diserap oleh tanaman apabila unsur hara tersebut berada dekat permukaan akar.

Produktivitas kedelai menunjukkan hasil rata-rata 1,76 ton/ha. Nilai tersebut lebih rendah dari potensi produksi menurut Balitkabi (2008) bahwa produktivitas varietas Anjasmoro yaitu 2,03-2,25 ton/ha dan hasil penelitian Handayani (2012) yang mencapai 2,40 ton/ha. Lebih rendahnya produktivitas tersebut disebabkan oleh kondisi lingkungan yang kurang mendukung untuk produksi kedelai, dosis pupuk kandang kambing yang belum mencukupi dan tidak adanya rhizobium. 
Tabel 3. Produksi kedelai dengan perlakuan dosis pupuk kandang kambing

\begin{tabular}{|c|c|c|c|c|c|c|c|c|c|c|c|}
\hline \multirow{2}{*}{ Peubah } & \multirow{2}{*}{$\begin{array}{c}\text { Umur } \\
\text { (MST) }\end{array}$} & \multirow{2}{*}{$\begin{array}{c}\mathrm{Uji} \\
\mathrm{F}\end{array}$} & \multicolumn{8}{|c|}{ Dosis pupuk kandang kambing } & \multirow{2}{*}{$\begin{array}{l}\text { Rata- } \\
\text { rata }\end{array}$} \\
\hline & & & 0 & & 6 & & 12 & & 18 & & \\
\hline $\begin{array}{l}\text { Jumlah tanaman } \\
\text { panen/petak }\end{array}$ & 12 & $*$ & 138,0 & $\mathrm{a}$ & 110,3 & $\mathrm{~b}$ & 129,3 & $\mathrm{a}$ & 130,5 & $\mathrm{a}$ & 127,0 \\
\hline Jumlah buku produktif & 12 & $*$ & 7,9 & $\mathrm{~b}$ & 8,3 & $\mathrm{~b}$ & 8,5 & $\mathrm{~b}$ & 9,4 & $\mathrm{a}$ & 8,0 \\
\hline $\begin{array}{l}\text { Jumlah } \\
\text { polong/tanaman }\end{array}$ & 12 & $*$ & 29,5 & $a b$ & 27,6 & $a b$ & 23,2 & $\mathrm{~b}$ & 34,5 & $\mathrm{a}$ & 28,7 \\
\hline $\begin{array}{l}\text { Jumlah polong } \\
\text { isi/tanaman }\end{array}$ & 12 & $*$ & 27,1 & $a b$ & 25,0 & $\mathrm{~b}$ & 21,5 & $\mathrm{~b}$ & 31,8 & $\mathrm{a}$ & 26,4 \\
\hline $\begin{array}{l}\text { Jumlah } \\
\text { polonghampa/tanaman }\end{array}$ & 12 & tn & 2,4 & & 2,5 & & 1,7 & & 1,5 & & 2,0 \\
\hline $\begin{array}{l}\text { BK biji petak } \\
\text { bersih }\left(\mathrm{g} / 7,2 \mathrm{~m}^{2}\right)\end{array}$ & 12 & tn & 1166,70 & & 1066,70 & & 1400,00 & & 1450,00 & & $\begin{array}{c}1270, \\
80\end{array}$ \\
\hline BK 100 biji (g) & 12 & tn & 12,98 & & 11,60 & & 12,87 & & 12,52 & & 12,49 \\
\hline $\begin{array}{l}\text { Produktivitas kedelai } \\
\text { (ton/ha) }\end{array}$ & 12 & tn & 1,61 & & 1,48 & & 1,93 & & 2,00 & & 1,76 \\
\hline
\end{tabular}

Tabel 4. Produksi kedelai dengan perlakuan cara aplikasi pupuk kandang kambing

\begin{tabular}{lccccc}
\hline \multirow{2}{*}{ Peubah } & \multirow{2}{*}{$\begin{array}{c}\text { Umur } \\
\text { (MST) }\end{array}$} & \multirow{2}{*}{ Uji } & \multicolumn{2}{c}{$\begin{array}{c}\text { Cara Aplikasi } \\
\text { Pemupukan }\end{array}$} & \multirow{2}{*}{ Rata-rata } \\
\cline { 1 - 1 } \cline { 5 - 6 } & & & dialur & disebar & \\
\hline Jumlah tanaman panen/petak & 12 & & 129,2 & 124,8 & 127,0 \\
Jumlah buku produktif & 12 & tn & 8,5 & 8,6 & 8,5 \\
Jumlah polong per tanaman & 12 & tn & 28,7 & 28,7 & 28,7 \\
Jumlah polong isi per tanaman & 12 & tn & 26,8 & 25,9 & 26,4 \\
Jumlah polong hampa per tanaman & 12 & tn & 1,8 & 2,1 & 2,0 \\
BK biji petak bersih $\left(\mathrm{g} / 7.2 \mathrm{~m}^{2}\right)$ & 12 & tn & 1308,30 & 1233,30 & 1270,70 \\
BK 100 biji (g) & 12 & tn & 12,83 & 12,16 & 12,49 \\
Produktivitas kedelai (ton/ha) & 12 & tn & 1,81 & 1,70 & 1,76 \\
\hline
\end{tabular}

Keterangan: Angka yang diikuti huruf berbeda pada baris yang sama menunjukkan berbeda nyata,tn:tidak nyata, (*) berbeda nyata taraf $5 \%,(* *)$ berbeda sangat nyata pada taraf $1 \%, \mathrm{KK}$ : koefisien keragaman, BK: bobot kering.

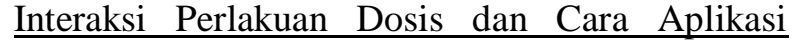
Pupuk Kandang Kambing terhadap Karakter Agronomi. Interaksi perlakuan dosis dan cara aplikasi pupuk kandang kambing berpengaruh nyata terhadap beberapa komponen karakter agronomi tanaman kedelai. Karakter agronomi yang dipengaruhi interaksi 2 faktoryaitu bobot basah akar 7 MST, jumlah polong per tanaman, dan jumlah polong isi per tanaman. Analisis interaksi terhadap peubah tersebut terdapat pada Tabel 9 dengan tujuan untuk melihat pola dan respon terbaik yang dihasilkan dari kombinasi perlakuan dosis dan cara aplikasi pupuk kandang kambing. Bobot basah akar 7 MST tertinggi terdapat pada interaksi antara perlakuan dosis 18 ton pupuk kandang kambing/ha dan cara aplikasi sebar dengan nilai rata-rata sebesar 5,73 g per tanaman. Bobot basah akar saat 7 MST terendah terdapat pada interaksi perlakuan dosis 0 ton pupuk kandang kambing/ha dan cara aplikasi sebar dengan nilai rata-rata sebesar $2,83 \mathrm{~g}$ per tanaman. Interaksi antara perlakuan dosis 18 ton pupuk kandang kambing/ha dan cara aplikasi sebar menunjukkan nilai tengah tertinggi pada peubah jumlah polong per tanaman dan jumlah polong isi per tanaman. 
Tabel 5. Pengaruh interaksi perlakuan dosis dan cara aplikasi pupuk kandang kambing terhadap beberapa karakter agronomi tanaman kedelai

\begin{tabular}{|c|c|c|c|}
\hline \multirow{2}{*}{ Dosis pupuk kandang kambing (ton/ha) } & \multicolumn{2}{|c|}{ Cara aplikasi pemupukan } & \multirow{2}{*}{ Rata-rata dosis pupuk kandang kambing } \\
\hline & dialur & Disebar & \\
\hline \multirow{2}{*}{\multicolumn{4}{|c|}{$\begin{array}{c}\text { Bobot basah akar } 7 \text { MST } \\
\text { (g per tanaman)* }\end{array}$}} \\
\hline & & & \\
\hline 0 & $3,22 \mathrm{bc}$ & $2,83 \mathrm{c}$ & 3,03 \\
\hline 6 & $3,34 b c$ & $4,00 \mathrm{~b}$ & 3,67 \\
\hline 12 & $4,04 \mathrm{~b}$ & $3,37 \mathrm{bc}$ & 3,72 \\
\hline 18 & $3,93 b c$ & $5,73 a$ & 4,80 \\
\hline rata-rata cara aplikasi & 3,62 & 3,98 & \\
\hline \multicolumn{4}{|c|}{ Jumlah polong per tanaman * } \\
\hline 0 & $34,5 \mathrm{ab}$ & $24,5 \mathrm{bcd}$ & 29,5 \\
\hline 6 & $22,9 \mathrm{~cd}$ & $32,4 a b c$ & 27,6 \\
\hline 12 & $26,5 \mathrm{bcd}$ & $19,9 \mathrm{~d}$ & 23,2 \\
\hline 18 & $31,1 \mathrm{abc}$ & $37,9 a$ & 34,5 \\
\hline rata-rata cara aplikasi & 28,7 & 28,7 & \\
\hline \multicolumn{4}{|c|}{ Jumlah polong isi per tanaman * } \\
\hline 0 & $31,6 \mathrm{ab}$ & $22,6 \mathrm{bcd}$ & 27,1 \\
\hline 6 & $21,0 \mathrm{~cd}$ & $29,0 \mathrm{abc}$ & 25,0 \\
\hline 12 & $24,7 \mathrm{abcd}$ & $18,3 \mathrm{~d}$ & 21,5 \\
\hline 18 & $29,9 a b c$ & $33,8 a$ & 31,9 \\
\hline rata-rata cara aplikasi & 26,8 & 25,9 & \\
\hline \multicolumn{4}{|c|}{ Bobot kering 100 butir biji $(\mathrm{g})^{* *}$} \\
\hline 0 & $13,47 \mathrm{abc}$ & $12,50 \mathrm{bcd}$ & 12,98 \\
\hline 6 & $11,07 \mathrm{~cd}$ & $12,13 \mathrm{bcd}$ & 11,60 \\
\hline 12 & $15,33 a$ & $10,40 \mathrm{~d}$ & 12,87 \\
\hline 18 & $11,43 \mathrm{bcd}$ & $13,60 \mathrm{ab}$ & 12,52 \\
\hline rata-rata cara aplikasi & 12,82 & 12,16 & \\
\hline
\end{tabular}

Keterangan: Angka yang diikuti huruf berbeda pada kolom yang sama berbeda nyata berdasarkan hasil Duncan's multiple range test (DMRT) pada taraf $\alpha=5 \%,(*)$ berbeda nyata pada taraf $5 \%,(* *)$ berbeda sangat nyata pada taraf $1 \%$.

Pola pengaruh interaksi dosis dan cara aplikasi pupuk kandang kambing terhadap peubah jumlah polong per tanaman, jumlah polong isi per tanaman, dan bobot basah akar 7 MST membentuk tren kurva kuadratik terbuka ke atas. Kurva jumlah polong per tanaman dan jumlah polong isi per tanaman membentuk pola yang sama yaitu cara aplikasi pupuk secara merata di permukaan tanah lebih tinggi daripada dalam alur. Kebutuhan dosis pupuk kandang kambing terus meningkat untuk menambah jumlah polong dan polong isi per tanaman pada cara aplikasi dalam alur maupun sebar. Hal ini berarti jumlah polong per tanaman dan jumlah polong isi per tanaman dapat ditingkatkan dengan melebihi dosis pupuk kandang kambing tertinggi yaitu 18 ton/ha.
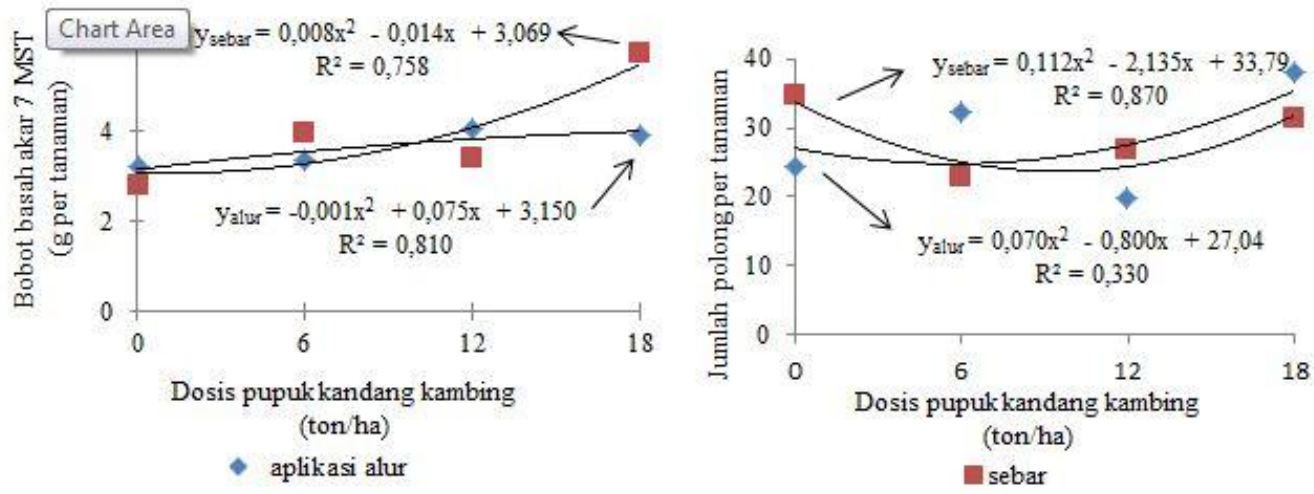

Gambar 1. Pengaruh interaksi dosis dan cara aplikasi pupuk kandang kambing (terhadap a) bobot basah akar 7 MST; (b) jumlah polong per tanaman. 


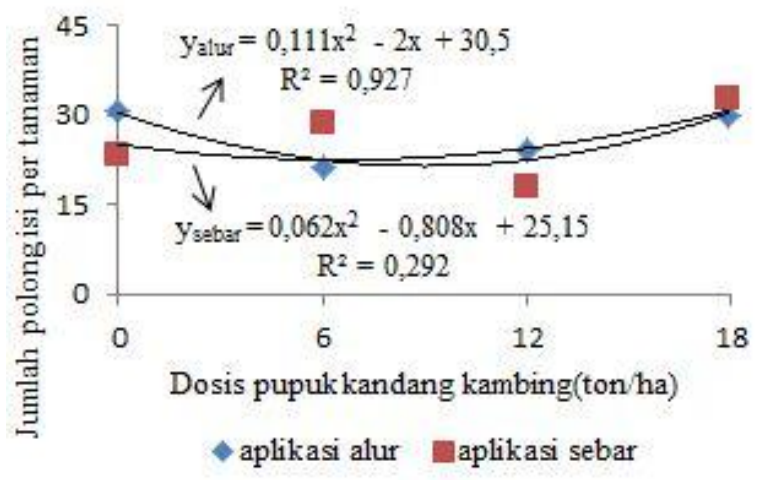

Gambar 2. Jumlah polong isi per tanaman berdasarkan interaksi dosis dan cara aplikasi pupuk kandang kambing

\section{KESIMPULAN}

Pemberian pupuk kandang kambing memperbaiki nilai peubah tinggi tanaman, jumlah daun, bobot basah dan kering akar, bobot basah dan kering bintil akar, bobot kering daun, jumlah tanaman panen/petak, jumlah buku produktif, jumlah polong per tanaman, dan jumlah polong isi per tanaman. Dosis 18 ton pupuk kandang kambing/ha memberikan peningkatan nilai peubah tersebut. Cara aplikasi pupuk kandang kambing memberikan pengaruh terhadap peubah bobot basah dan kering tajuk dan daun. Cara aplikasi pupuk kandang kambing pada peubah produksi menghasilkan pengaruh yang tidak nyata. Hal tersebut diduga akibat cara aplikasi rekomendasi belum diperoleh untuk produksi kedelai sehingga kedua cara tersebut masih boleh digunakan karena tidak menyebabkan perbedaan hasil yang besar. Terdapat pengaruh interaksi perlakuan dosis pupuk dan cara aplikasi pupuk kandang kambing terhadap peubah bobot basah akar 7 MST, jumlah polong per tanaman, dan jumlah polong isi per tanaman.

\section{DAFTAR PUSTAKA}

Asiah, A. 2006. Pengaruh kombinasi pupuk organik terhadap pertumbuhan dan produksi kedelai (Glycine max (L) Merr) panen muda dengan budidaya organik. Skripsi. Institut Pertanian Bogor. Bogor.

Balai Penelitian Tanaman Kacang-kacangan dan Umbi-umbian. 2008. Deskripsi Varietas Unggul Kacang-kacangan dan Umbiumbian. Balai Penelitian Tanaman Kacang-kacangan dan Umbi-umbian, Bogor.

Dinariani., Y.B.S. Heddy, B Guritno. 2014. Kajian penambahan pupuk kandang kambing dan kerapatan tanaman yang berbeda pada pertumbuhan dan hasil tanaman jagung manis (Zea mays saccharata Sturt). J Produksi Tanaman. 2(2): 128-136.

Handayani, T.A. 2012. Produksi kedelai organik berdasarkan perbedaan dosis pupuk dan fungi mikoriza arbuskula. Skripsi. Institut Pertanian Bogor. Bogor.

Hardjowigeno, S. 2007. Ilmu Tanah. Akademika Pressindo, Jakarta.

Hartatik, W., L.R. Widowati. 2005. Pupuk kandang dan pupuk hayati. Warta Penelitian dan Pengembangan Pertanian. 29(4):59-82.

Jumini, Nurhayati, Murzani. 2011. Efek kombinasi dosis pupuk N P K dan cara pemupukan terhadap pertumbuhan dan hasil jagung manis. J. Floratek. 6:165170.

Kasno, A., Nurjaya, D.S Ardi. 2009. Neraca hara $\mathrm{N}$, $\mathrm{P}$, dan $\mathrm{K}$ pada pengelolaan hara terpadu lahan sawah bermineral liat campuran 1:1. Prosiding Semiloka Nasional Inovasi Sumberdaya Lahan: Inovasi teknologi Sumberdaya Lahan Mendukung Sistem Pertanian Industrial. Bogor, 24-25 November 2009.

Kurniansyah, D. 2010. Produksi kedelai organik panen kering dari dua varietas kedelai dengan berbagai jenis pupuk organik. Skripsi. Institut Pertanian Bogor. Bogor.

Lakitan, B. 1995. Hortikultura: Teori, Budidaya, dan Pasca Panen. PT. Raja Grafindo Persada, Jakarta. 
Lestari, S.A.D. 2011. Pengaruh bahan organik dan jenis decomposer terhadap pertumbuhan dan produksi kedelai (Glycine max (L) Merril). Skripsi. Institut Pertanian Bogor. Bogor.

Lingga, P. 1991. Jenis dan Kandungan Hara pada Beberapa Kotoran Ternak: Pusat Pelatihan Pertanian dan Pedesaan Swadaya. Antanan, Bogor.

Marwoto, Suharsono. 2008. Strategi dan komponen teknologi pengendalian ulat grayak (Spodoptera litura Fabricius) pada tanaman kedelai. J.Libangtan. 27(4):131136.

Melati M., W. Andriyani . 2005. Pengaruh pupuk kandang ayam dan pupuk hijau Colopogonium mucunoides terhadap pertumbuhan dan produksi kedelai panen muda yang dibudidayakan secara organik. Bul Agron. 33 (2):8-15.

Melati, M., A. Asiah, D. Rianawati. 2008. Aplikasi pupuk organik dan residunya untuk produksi kedelai panen muda. Bul Agron. 36(3):204-213.

Meliala, M.G. 2011. Produksi dua varietas kedelai organik akibat pemberian pupuk dengan dosis yang sama dengan dosis musim tanam I. Skripsi. Institut Pertanian Bogor. Bogor.

Purwono, H. Purnamawati. 2007. Budidaya 8 Jenis Tanaman Pangan Unggul. Penebar Swadaya, Jakarta.

[PPT] Pusat Penelitian Tanah. 1983. Jenis dan Macam Tanah di Indonesia untuk Keperluan Survey dan Pemetaan Tanah Daerah Transmigrasi. Pusat Penelitian Tanah, Bogor.

Rozaq, P., N. Sofriani. 2009. Organic Pecticide from Urine and Spices Modification.
Karya Ilmiah. Fakultas Pertanian Institut Pertanian Bogor. Bogor.

Roziqin, K. 2014. Fungi mikoriza arbuskula dan keberadaan inangnya dapat memperbaiki pertumbuhan kedelai organik. Skripsi. Institut Pertanian Bogor. Bogor.

Santoso, B., F. Haryanti, S.A. Kadarsih. 2004. Pengaruh Pemberian Pupuk Kandang Ayam terhadap Pertumbuhan dan Produksi Serat Tiga Klon Rami di Lahan Aluvial Malang. Balai Penelitian Tanaman Tembakau dan Serat, Malang.

Sarief, E.S. 1986. Kesuburan dan Pemupukan Tanah Pertanian. Pustaka Buana, Bandung.

Simanungkalit, R.D.M., D.A. Suriadikarta. 2006. Pupuk Organik dan Hayati, Organic Fertilizer and Biofertilizer. Simanungkalit R.D.M., Suriadikarta D.A., Saraswati R., Diah S., dan Hartatik W, editor. Balai Besar Penelitian dan Pengembangan Sumberdaya Lahan Pertanian, Bogor.

Sumarno, A.G. Manshuri. 2007. Persyaratan tumbuh dan wilayah produksi kedelai di Indonesia. Dalam: Sumarno, Suyamto A., Widjono, Hermanto, dan Kasim H (Eds). Pusat Penelitian dan Pengembangan Tanaman Pangan. Badan Penelitian dan Pengembangan Pertanian. Bogor.

Sutedjo, M.M. 1994. Pupuk dan Cara Pemupukan Cetakan ke-4. Rineka Cipta, Jakarta.

Vitosh, M.L., J.W. Johnson, D.B. Mengel. 1995. Tri-state fertilizer recommendation for corn, soybean, wheat, and alfafa. Michigan State University, East Lansing Michigan. USA.

Winarni, E., R.D. Ratnani, I. Riwayati. 2013. Pengaruh jenis pupuk organik terhadap pertumbuhan tanaman kopi. Momentum. 9(1):35-39. 